\title{
Post-Soviet Agricultural Restructuring: A Success Story After All?
}

\author{
Martin Petrick ${ }^{1,2}$ (D)
}

Accepted: 19 September 2021 / Published online: 5 October 2021

(C) The Author(s) 2021

\begin{abstract}
Challenging the initial expectation that all post-Soviet economies will evolve from collective toward fully individualized farming, I argue that they separated into two different reform paths. In the European successor countries and Kazakhstan, corporate and family farms coexist, labor exited agriculture, and capital inflow boosted labor productivity (a "Westernization"). In the Transcaucasian and the other Central Asian countries, complete farm individualization did not increase labor productivity much, in turn keeping rural incomes depressed (a "Southernization" akin to the Global South). Future policies should promote income alternatives to agriculture and improve the flexibility and transparency of farm consolidation processes.
\end{abstract}

Keywords Agricultural restructuring · Post-Soviet countries · Labor productivity · Individual farm

JEL E23 $\cdot \mathrm{P} 27 \cdot \mathrm{P} 32 \cdot \mathrm{Q} 15$

\section{Introduction}

In the agricultural sector, the collapse of the Soviet Union pushed open an arena of reform debate and restructuring policies that has not closed 30 years later. From the Baltic countries to Central Asia and the Far East, the socialist era bequeathed its collective and state farms to the newly independent states. In the decades to follow, policymakers, analysts as well as farm managers and rural workers would struggle with restructuring the former collectives into alternative farming models considered fit for the envisaged market economy.

Martin Petrick

martin.petrick@agrar.uni-giessen.de

1 Center for International Development and Environmental Research (ZEU), Justus-LiebigUniversität Gießen, Senckenbergstraße 3, 35390 Gießen, Germany

2 Leibniz Institute of Agricultural Development in Transition Economies (IAMO), Halle (Saale), Germany 
Before its ultimate demise, Soviet agriculture provided income to more than one quarter of the workforce, much more than in Western market economies (Lerman et al. 2004, p. 14). Widely considered as overstaffed, inefficient and import-dependent, the post-Soviet food economy also drew on vast resources of crop and pasture land, thus alluring investors with an eye on rising domestic demand and export opportunities. Land privatization and the creation of land sales and rental markets emerged as contentious political issues (Pryor 1992).

Many Western economists considered the family farm, such as portrayed in Kislev and Peterson (1982), as the natural benchmark for reform. Based on the perceived superiority of family-led operations with regard to technical, allocative and innovative efficiency, international advisors recommended to split up ("individualize") the former collectives into private family farms, to thus return control and ownership rights to producers, improve their incentives to elicit more effort and reduce the operational size of farming units (World Bank 1992, pp. 69-77; Lerman et al. 2004, pp. 49-51).

In the years to come, highly varying privatization and reform policies across the region turned the set of post-socialist countries into a laboratory of farm restructuring. After the first transition decade, Swinnen and Rozelle (2006) documented how land restitution, the rise of land rental and the recapitalization of large farms had spurred notable productivity growth in Central and Eastern European agriculture. They observed even stronger growth in East Asia, where the property rights reform of the Household Responsibility System in China alone had created millions of family farms.

Compared to these two groups of countries, the reform results in the Soviet successors known as the Commonwealth of Independent States (CIS) were dismal. In the land-abundant European and most of the Central Asian CIS countries, little restructuring had taken place, substantial property rights reforms had failed to materialize, and both output and productivity indicators had plummeted into an ever deeper trough. Rural public opinion often favored the continuation of large-scale farming, thus challenging Western reform templates. Where political conditions allowed open discourse, such as in Russia, political representatives and national experts disagreed strongly on the desirable restructuring model, often leading to reform resistance and political stalemate (Van Atta 1993; Wegren 2005, pp. 52-59).

Against this background, my aim here is to take stock of farm individualization, land reform and productivity dynamics in post-Soviet agriculture another two decades later. I organize the analysis around the guiding hypothesis-articulated by the international mainstream of experts - that strong property rights and the full individualization of farming are the key drivers of productivity increases in the former Soviet countries. I thus ask, in their second and third decade of transition, did these countries manage to emulate what Central Europe and East Asia accomplished in their first reform decade, as Swinnen and Rozelle conjectured (2006, p. 184)? How did farm restructuring progress and which role did it play in productivity growth? Which long-run development trajectories of agricultural sector evolution emerged? How should we qualify the initial expectations about farm individualization and the role of family farms? 
In the following empirical analysis, I examine agricultural input and output indicators at the country level published by international agencies, as well as updated national statistics on farm restructuring that are not available in the English-speaking literature to date. While a more in-depth and micro-level empirical analysis is beyond the scope of this paper, I refer to recent research findings in the literature using more advanced methodology and fine-grained data wherever suitable.

Challenging the view that all countries will ultimately evolve toward a fully individualized farming sector, I argue that, over the past two decades, the bulk of the post-Soviet countries separated into two different reform paths in agriculture. One cluster includes the European CIS countries and Kazakhstan, in which corporate and family farms coexist, labor flowed into other sectors, and capital inflow boosted labor productivity. I call this the "Westernization" of post-Soviet agriculture, as it resembles the structural change observed in many Western countries (such as the US, Sumner 2014).

The other cluster comprises the Transcaucasian and the remaining Central Asian countries, in which almost complete farm individualization coincided with substantial growth of the agricultural labor force. Productivity increases from individualization thus did not contribute much to rising labor productivity, in turn keeping rural incomes depressed and perpetuating pockets of poverty in the region. I call this process the "Southernization" of agriculture, alluding to patterns of agricultural overemployment observed in the Global South (Gollin et al. 2014).

I critically examine the definition of "individual farming" in the post-Soviet reform discourse and link it to a recent strand of literature reasoning that small farms typically do not fulfil the income expectations of would-be middle-class families (Adamopoulos and Restuccia 2014; Gollin 2018). In contrast to much of the literature on post-Soviet farm restructuring but in line with this more recent strand, I conclude that given the yardstick of labor productivity, the individual family farm turned out to be a questionable reform template. Based on a review of the literature on restructuring outcomes in the region, I highlight areas for further research.

In the following, I start with summarizing the expectations voiced by international experts at the outset of post-Soviet farm restructuring. After a section introducing my metrics and data, I examine the output and productivity trends as well as the individualization and land reform outcomes. I present figures on country aggregates and review a range of more in-depth studies from the literature. After a discussion of the major drivers and barriers in the reform process, I conclude with an overall evaluation of the restructuring experience.

\section{Initial Expectations About Post-socialist Agricultural Restructuring}

At the outset of transition from Soviet-style socialism to capitalism in agriculture, most of the influential Western advisors held the view that meaningful restructuring had to imply the creation of smaller family-run farming units based on private property of land and embedded in a liberalized market environment. The proponents of such farm individualization, many of them affiliated with the World Bank, argued that collectivization as an economic development strategy had failed historically 
(Johnson 1993) and that strong property rights in land would create superior investment incentives compared to collective farms (Stiglitz 1993). In the absence of economies of scale in agricultural production, smaller family farms would face fewer problems of managerial control and worker supervision (Schmitt 1991; World Bank 1992; Stiglitz 1993). A massive body of international evidence seemed to prove the economic superiority of owner-operated family farms (Binswanger et al. 1995), and the early reform experience of China and Vietnam in the 1980s suggested that rapid output growth would be expected from de-collectivization and downsizing (Lerman 1998).

Against these premises of a "family farm theory," reformers recommended a comprehensive shift to individual farming as highly desirable. In this view, "transition" unleashed a competition among former collective farms and their formal successors on the one hand and emerging individual farms on the other. The breakthrough of individual farming would even be evolutionarily inevitable unless blocked by government interventions privileging the status quo (Binswanger et al. 1995; Sarris et al. 1999). Such arguments culminated in the claim that all countries embarking on an individualization path will experience rising productivity levels in agriculture (Lerman 1998, p. 311; Lerman 2017; Lerman and Sedik 2018). The goal of "transition" was clearly defined (Lerman et al. 2004, pp. 49-51).

At the same time, many analysts foresaw the massive obstacles that such decollectivization would confront. These ranged from the absence of reliable output and input markets including credit, over the challenge of risk management, to social and political factors such as the lack of entrepreneurial skills of peasants and the resistance by cadres or politicians, due to ideological reservations or vested interests (Pryor 1992, pp. 265-295). The apt book title "The 'Farmer Threat'-The Political Economy of Agrarian Reform in Post-Soviet Russia” by Van Atta (1993) emphasized how such massive shifts in farm organization would face political resistance.

\section{Metrics and Data}

Following Swinnen and Rozelle (2006, pp. 13-14) and much of the literature on economic transition, I focus on output and productivity growth as the key performance indicators of agricultural reform. Food serves immediate human consumption needs, whereas a thriving agricultural sector secures and raises rural incomes and, in addition to non-food commodities, allows the generation of export revenues. While change in total factor productivity (TFP) represents a comprehensive indicator of an economically successful restructuring, due to data limitations, I focus on agricultural labor productivity as a metric of factor use efficiency and a key determinant of income generation potential (Gollin et al. 2014; Gollin 2018). 
By investigating the progress of land individualization, I also assess the redistributive effects of restructuring. Farm individualization potentially contributes to a more equal access to resources, especially if it is accompanied by redistributive land reform (Lipton and Saghai 2017). ${ }^{1}$ Evaluating the effects of restructuring on the natural environment is beyond the scope of this article. ${ }^{2}$

The subsequent analysis draws on country-level indices of agricultural output published by the Statistics Division of the United Nation's Food and Agricultural Organization (FAO), i.e., the Gross Production Index Number (2014-2016=100) for total agriculture per country (FAO 2021). Agricultural output includes series of gross agricultural output (GAO), crops, and livestock. GAO is net of seeds and fodder and includes technical crops. Livestock includes processed dairy products and technical products derived from animals, such as wool or skins.

Indices are composed of quantities weighted by constant 2014-2016 international prices. This procedure avoids biases due to fluctuating exchange rates, domestic hyperinflation or price controls.

Moreover, I use data on the number of persons in the labor force and the share of employment in agriculture calculated by the International Labor Organization (ILO), as published in the World Development Indicators by the World Bank (World Bank 2020). Labor input is the modeled ILO estimate of employment in agriculture, hunting, forestry and fishing.

ILO does not provide very detailed information on how it did the country-specific modeling. I cannot rule out that agricultural labor is inconsistently defined across countries and it almost surely includes imputed values. Problems may arise if workers are counted as full-time when they effectively spend a part of their time on other activities, if they temporarily migrated to urban centers or abroad. Alternatively, informal employment or forced labor may be underreported in official statistics. In the first case, agricultural labor productivity is underestimated; in the second it is overestimated. ${ }^{3}$ The labor data cannot be disaggregated into different farm types. My main purpose is to investigate the relative trends in labor use over time across countries. $^{4}$

For the subsequent figures, I re-based and aggregated the indices to examine output and productivity trends in the three decades after the start of reforms.

Finally, I process data on land use and the composition of GAO by farm type, published by the national statistical offices across the region. While the terminology slightly varies across countries, these data generally distinguish agricultural enterprises, individual farms and rural households. I use it to trace the change in farm

\footnotetext{
1 Land reform as such does not guarantee though that every beneficiary has a fair chance to receive his/ her share, and that this happens in a transparent manner (see e.g., Allina-Pisano 2008).

2 As a first orientation, note that economic decline in the course of transition had involved a widespread reduction in input use and the abandonment of large tracts of cropland (Schierhorn et al. 2013).

3 See Swinnen and Rozelle (2006, pp. 26-27) for further discussion of labor measurement problems in transition agriculture.

4 This approach obviously conceals heterogeneity within countries. Some countries may exhibit regionally different trajectories in farm restructuring akin to the ones presented here in cross-country comparison.
} 
individualization, to be further discussed below. Often the successor organizations of the former collective farms in the early transition period, agricultural enterprises represent the corporate sector.

\section{Output and Productivity Trends}

In this section, I distinguish five country aggregates according to broad socioeconomic and agro-ecological criteria (Table 1). Central Europe represents the successful reform benchmark as indicated by Swinnen and Rozelle (2006). The Baltics form a separate group of Soviet successor countries which are close in many ways to Central Europe. I bundle the land-rich CIS countries in the European steppe zone together with Kazakhstan as they are characterized by similar agro-ecological conditions and production technologies. The Transcaucasian countries and Central Asia represent two distinct groups of their own, the first one dominated by heterogeneous farming conditions with an important share of multiannual crops such as orchards and vineyards, and the second one by irrigated cotton and wheat mono-cropping. Aggregate indicators below represent group averages weighted by annual arable land per country as reported by FAO. ${ }^{5}$

Table 1 illustrates the concentration of agricultural resources in the European CIS countries and Kazakhstan. However, the table also shows that the employment shares of Central Europe, Transcaucasus and Central Asia are larger than their shares in arable land, so that the worker-to-land ratio is higher in these countries.

Over 30 years, total agricultural output changed quite little in the successfully reforming countries of Central Europe (Fig. 1). Especially during the first reform decade, this group of countries apparently was least affected by the disruptions of transition caused by price reforms, privatization, disorganization and recovering efficiency as analyzed, for example, in Swinnen and Rozelle (2006, pp. 28-49).

The Central Europe line illustratively divides the other countries into two sets. Output in the Transcaucasus and Central Asia took off after the first transition decade and doubled in the 20 years afterward. Output in the European CIS and the Baltics, on the other hand, plummeted. Contributing the overwhelming share of agricultural output in the region under study, it took for the European CIS countries and Kazakhstan 25 years to return to the Soviet production levels. The Baltic countries so far did not even accomplish that. Livestock production in Europe never recovered (appendix, Fig. 7). I turn to some explanations for these patterns below.

With regard to labor use and resulting labor productivity, the picture looks very different. Central Europe and the Baltics display the largest outflow of agricultural labor (appendix, Fig. 8) and the steepest increase in labor productivity (Fig. 2). At the same time, agricultural employment rose massively in the Transcaucasus and Central Asia, and these countries lag much behind in labor productivity. In the European CIS and Kazakhstan, labor shedding accelerated recently, and this country

\footnotetext{
5 Data for the Czech and Slovak Republics are not available for 1992. I assumed all indicators stayed constant from 1992 to 1993 for these two countries.
} 


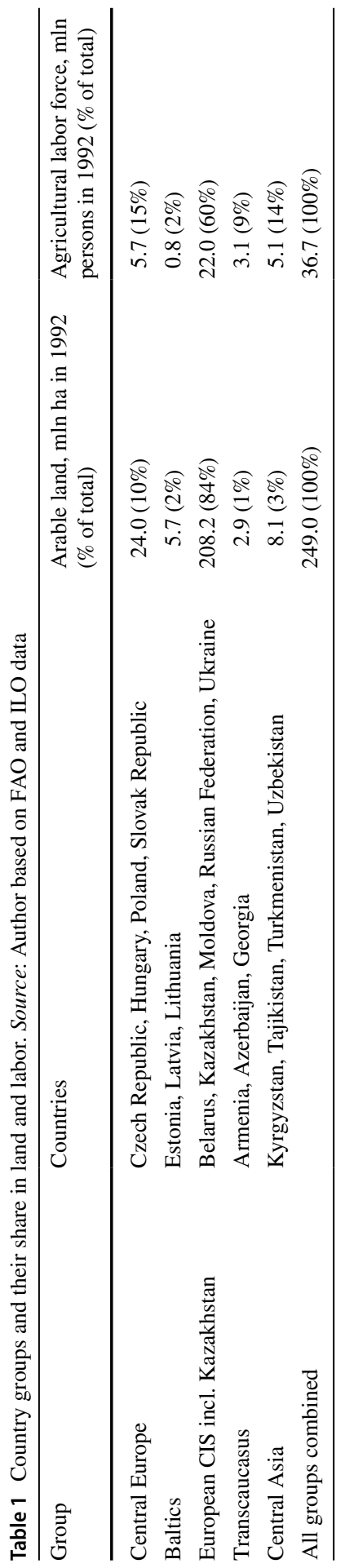




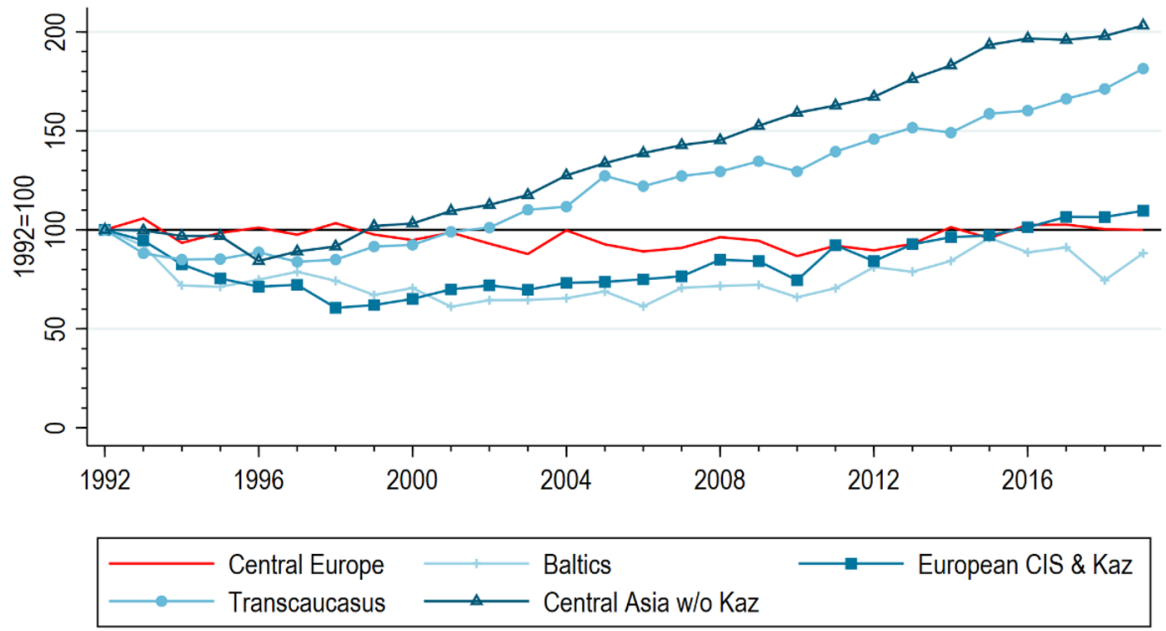

Fig. 1 Gross agricultural output change in post-socialist country groups $(1992=100)$, 1992-2019. Source: Author based on FAO data

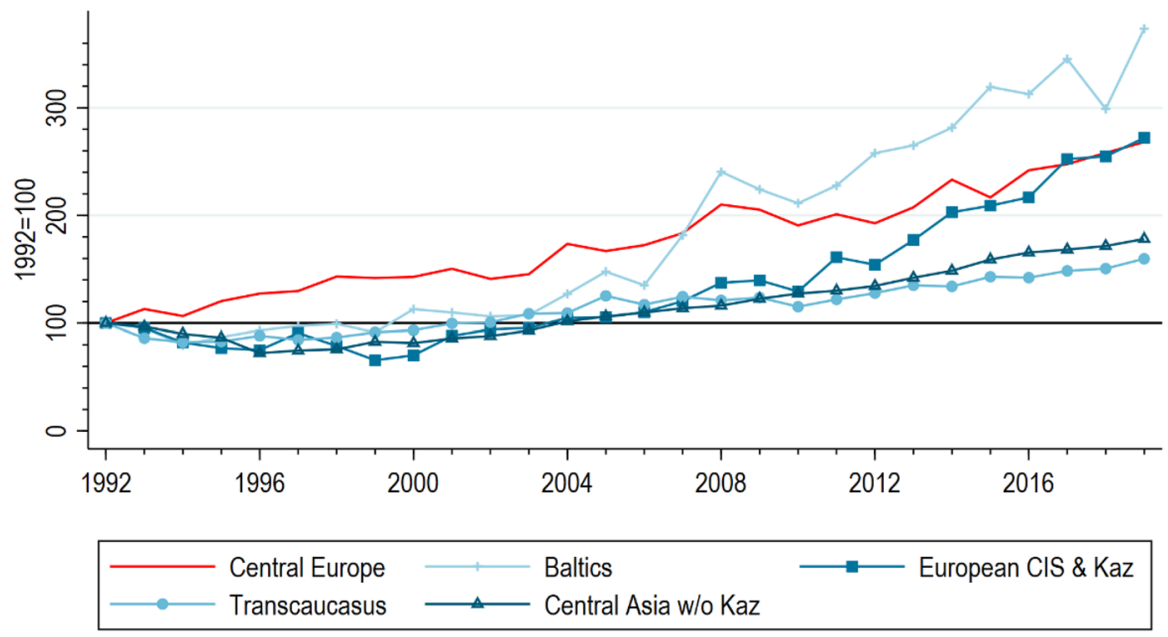

Fig. 2 Agricultural labor productivity, 1992-2019. Source: Author's calculations based on FAO and ILO data

group managed to catch up with Central European labor productivity levels only a few years ago. 


\section{Individualization and the Nature of Individual Farming}

Using the term "individualization" for the breakup of former collective farms distracts from the fact that individual or "private" agricultural production among village households had been a cornerstone of Soviet food supply for decades (Wädekin 1973). For this reason, official statistics in most CIS countries separate the individual sector further. They disaggregate it, on the one hand, into "individual" or "peasant" farms or "fermer" (sic!) units that emerged as a new phenomenon in the 1990s, and rural households that existed as a category before, on the other. Even so, some scholars indiscriminately assign the label of "individual" or "smallholder" farm to a whole set of different production practices that have little in common.

Unfortunately, the statistical classification does not necessarily demarcate the line between commercial and subsistence producers. In countries with a farm structure dominated by smallholders in general, it may be a purely administrative decision whether an operation counts as individual farm or household. For example, in Azerbaijan, the individualized sector is almost entirely represented by rural households (Fig. 9).

At the other extreme, in land-rich countries, individual producers may have access to large tracts of land. The 2016 agricultural census in Russia identified "peasant farms" that cultivate 40,000 hectares (Yanbykh et al. 2020, p. 27). Across the CIS region, "individual" production units thus range from kitchen gardens in the vicinity of urban centers to commercial crop farms cultivating several hundred hectares and employing dozens of workers in the Eurasian steppe (Pallot and Nefedova 2007; Petrick et al. 2013).

In addition, individualization does not necessarily mean that farmers possess full freedom of decision making and property rights in their assets. Even after full "individualization," governments or local elites have continued to exert substantial control over production decision in many countries. This typically applies to individual farmers, not households. Cotton producers in Tajikistan and Uzbekistan represent extreme cases of elite control (Hofman 2018; Veldwisch and Spoor 2008).

Current statistics show that rural households continue to cultivate substantial fractions of land in almost all countries and contribute even larger shares to total output (Figs. 9 and 10). It follows directly that rural households display a higher land productivity than the other farm types. Most analysts consider the household sector as static, whereas substantial growth in land use and output occurred among the emerging individual farmers (Pallot and Nefedova 2007). Lacking the data about the specific commercial orientation of producers by country, I bundle together households and individual farms as the "individual sector" in the following statistics, keeping in mind its considerable internal heterogeneity. 


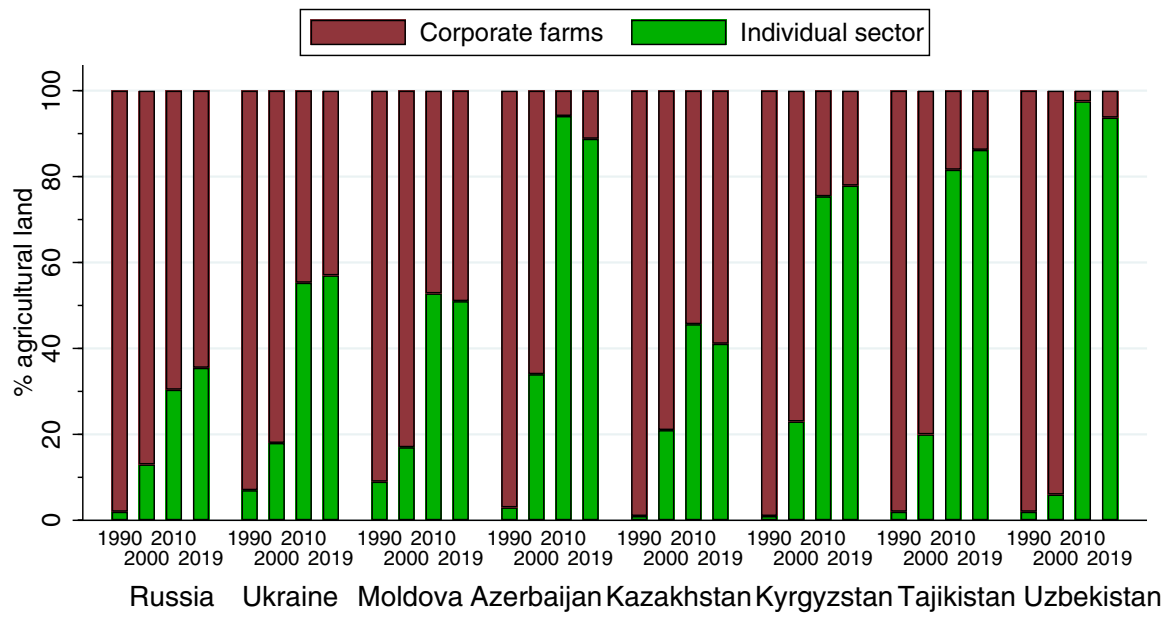

Fig. 3 Use of agricultural land by farm type, 1990-2019. Note: Individual sector includes individual farms and rural households. Agricultural land measured as sown area in Azerbaijan, Kazakhstan, Kyrgyzstan, Tajikistan and Uzbekistan. Source: National statistical offices, Lerman et al. (2004, p. 113) for 1990 and 2000

\section{Recent Trends in Farm Restructuring}

In light of the initial reform expectations outlined before, it may come as a surprise that the Central European countries did not follow a path of full farm individualization. Although generally considered a success story in agricultural restructuring, the privatization process left a considerable share of land in corporate farms. In Central Europe, privatization mostly proceeded via the restitution of farmland to former owners rather than through the redistribution of property titles to workers, as in the CIS (Lerman et al. 2004, pp. 105-162). Restitution favored the persistence of corporate farms, as the new owners often had no intention to cultivate the land themselves and thus found it cost-effective to rent it to the existing large-scale farms (Swinnen and Rozelle 2006, pp. 60-62). As a result of overall economic reform progress in Central Europe, farm managers soon faced hard budget constraints and other market incentives. Similar conditions quickly emerged in the Baltic countries as well. ${ }^{6}$

I thus focus on the remaining three groups of countries, in which restructuring faced more obstacles. In Fig. 3, Russia, Ukraine and Moldova represent the European CIS countries joined by Kazakhstan, Azerbaijan, the Transcaucasus, and Kyrgyzstan, Tajikistan and Uzbekistan (the rest of), Central Asia. For ease of exposition, I limit the empirical analysis to these eight countries. ${ }^{7}$

\footnotetext{
6 In 2000, the share of corporate farms in agricultural land stood at $62 \%$ in the Czech Republic, $48 \%$ in Estonia, 9\% in Latvia, 10\% in Lithuania, 46\% in Hungary, 18\% in Poland and $91 \%$ in the Slovak Republic (Lerman et al. 2004, p. 113).

7 Due to the continuation of massive state dirigisme after the end of the Soviet Union, individual farming hardly took root outside of rural households in Belarus and Turkmenistan. Armenia and Georgia followed similar restructuring patterns as Azerbaijan (Lerman et al. 2004).
} 
In the first decade of transition, except in Azerbaijan and perhaps Kyrgyzstan, farm individualization across the region proceeded slowly. After the turn of the millennium, individualization took a leap forward again in Azerbaijan, but now also in all the Central Asian countries. Of these, only Kazakhstan left more than half of the land in corporate farms and thus followed the pattern also observed in the European "breadbaskets" Russia, Ukraine and Moldova. The third decade hardly witnessed any further shifts in individualization. Corporate farms slightly expanded their area again in several of the countries listed. Large farms thus endured as a major group of land users in the group of European CIS countries plus Kazakhstan, but speaking of a recent "significant decline in smallholder farming" (Burkitbayeva and Swinnen 2018, p. 890) seems premature.

While a comprehensive overview of recent developments in farm restructuring is beyond the scope of this article, I highlight some of the salient issues.

Among the three countries with the largest reserves of cropland, Russia, Ukraine and Kazakhstan, Russia progressed the most in terms of land privatization (Shagaida and Lerman 2017). However, in Russia as well as in its two neighbors, land often changes ownership or moves to new users via the acquisition of whole farms, not land plots. This led to the emergence of the so-called agro-holdings, i.e., vertically and horizontally integrated conglomerates that control huge tracts of land, sometimes in different provinces (Rylko et al. 2008; Visser et al. 2012). At the same time, individual farms have stepped out of their role as niche producers and are gaining recognition as a potentially strategic force of sector development by the government (Wegren 2011; Petrick and Götz 2019).

Ukraine endured a long period of legal uncertainty concerning the end of a land sales moratorium put in place in the 1990s (Lerman et al. 2007). The current government plans to open a land sales market in summer 2021. However, issues of transparency, ownership concentration and market power remain (Lapa et al. 2015; Graubner et al. 2021).

While Ukrainians worry about land purchases by Russian investors, Kazakhstanis are concerned about growing influence of Chinese buyers. Against the initial individualization progress in the 1990s, the 2003 introduction of a new land code in Kazakhstan had little effect on farm restructuring (Kvartiuk and Petrick 2021). Often deeply in financial debts, agro-holdings control a major share of cropland in the northern steppe regions. At the same time, the rural population seems to widely support the idea of corporate farming (Petrick et al. 2013).

Many livestock herds formerly held in collective farms collapsed in the early transition period. However, individualized animal husbandry thrived in subsequent decades, especially in the Transcaucasus and Central Asia. Smallholders depend on pasture access, which in many countries remains poorly regulated (Robinson and Petrick 2021, pp. 23-36). Corporate livestock operations reentered the scene only recently, partially encouraged by generous state protection (Nefedova 2017; Petrick and Götz 2019). 


\section{Drivers and Barriers of Restructuring Progress}

Looking back on the first decade of transition, Swinnen and Rozelle (2006) plausibly summarized the main reasons for the massive output decline in the European CIS countries. In the early years, a negative terms-of-trade effect due to the abandonment of producer price bonuses and input subsidies depressed profitability. Moreover, market liberalization caused massive disorganization costs, as the existing support and marketing network dismantled and was not replaced quickly. The widespread uncertainty about property rights reform in the CIS diluted incentives more than in other transition countries (pp. 34-47; 155-156).

Many economists considered the latter aspect as decisive also in the longer term. With the exceptions of Azerbaijan and Kyrgyzstan, land reform in all of the countries listed in Fig. 3 initially involved the distribution of paper shares, often with little transparency to beneficiaries and no clear demarcation of land plots (Lerman et al. 2004). Land sales and rental markets emerged only slowly. Governments usually remained the formal owners of agricultural land. Operators thus faced restricted use rights and could rarely enforce them legally.

Local stakeholders and even potential beneficiaries from asset redistribution and privatization supported the reforms much less than in East Asia. A plausible reason is that rural workers of the former Soviet Union had much more to lose, such as bread subsidies, social services provided by the collectives, access to large farming technology, and they worried about a much higher risk exposure under market competition (Pryor 1992, pp. 265-290; Swinnen and Rozelle 2006, pp. 109-115).

Officials and bureaucrats at the local level opposed reforms for similar reasons. In addition, full individualization might have deprived them of their political influence and privileges. Using their power to control the information flow and the implementation of centrally administered de-collectivization campaigns, they sometimes overtly manipulated the rural population to oppose restructuring (Allina-Pisano 2008; Petrick and Carter 2009).

After the turn of the millennium, rising commodity prices and expanding urban demand for food helped Russian agricultural output to return to a growth path. Governments stepped up their support budgets in both Russia and Kazakhstan (Uzun et al. 2019; Petrick et al. 2017). Political elites across the region maintained a strong interest in tradable agricultural commodities and continued to tamper with farm restructuring in their favor. Agricultural subsidies in Russia primarily reach the largest producers, the agro-holdings, which are often linked to domestic investors from other sectors (Uzun et al. 2019). They also benefit from Russia's import substitution policy, at the cost of higher domestic consumer prices (Sedik et al. 2018). These government interventions make it difficult to assess the international competitiveness of producers. At the same time, subsidies did little to prevent the mass migration from the countryside to the cities (Nefedova 2017).

Political interest in cotton exports has determined Uzbekistan's restructuring policies for most of the post-independence period (Veldwisch and Spoor 2008; Djanibekov et al. 2012). The country underwent various stages of top-down "optimization" and "clustering" of farm operations (Zorya et al. 2019). In Tajikistan, despite formal 


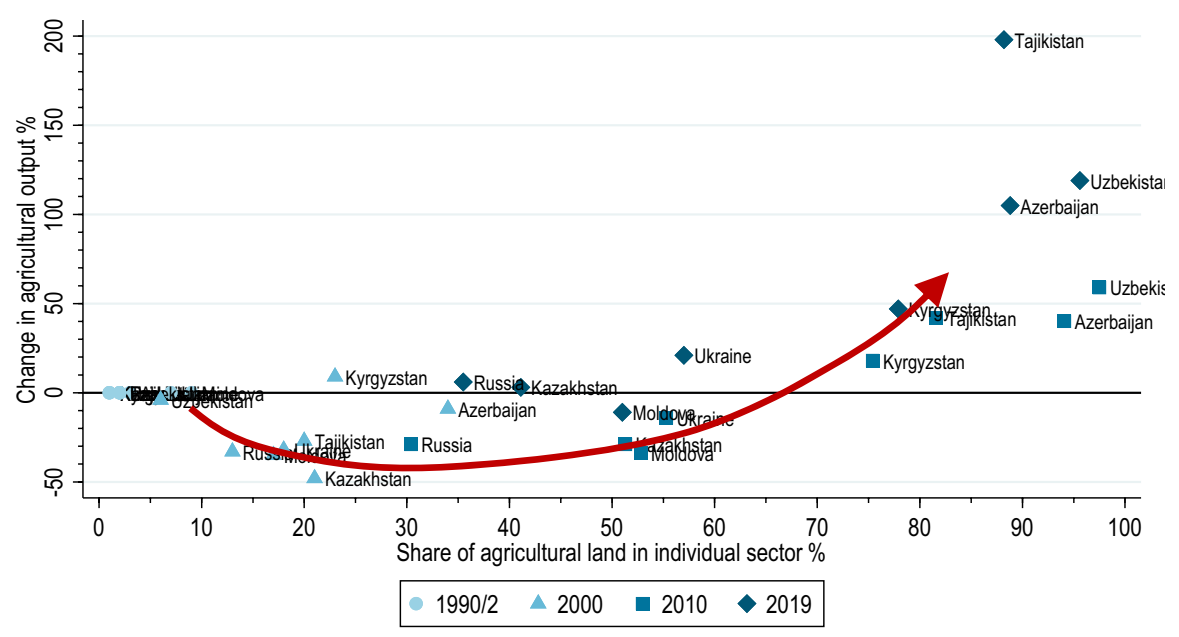

Fig. 4 Farm individualization and output change (\%), 1990-2019. Note: output change is relative to 1992. Individual sector includes individual farms and rural households. Agricultural land measured as sown area in Azerbaijan, Kazakhstan, Kyrgyzstan, Tajikistan and Uzbekistan. Source: as in Fig. 1 and Fig. 3

farm restructuring, informal political influence in the cotton sector continues to loom large (Hofman 2018).

Despite the ongoing political meddling, the almost spectacular output growth in Central Asia and the Transcaucasus has probably much less to do with politics than in the European CIS (Fig. 1). While there is little systematic analysis available, the sheer population growth will have induced land use intensification processes that are also traditionally observed in the Global South (Boserup 1965). Casual evidence suggests that tenants in Central Asia increasingly practice double and second cropping and intensify the cultivation of high-value crops such as fruits and vegetables on household plots and kitchen gardens (Mukhamedova and Pomfret 2019). In Azerbaijan, Tajikistan and Uzbekistan, the contribution of households to total output is highest across the region (Fig. 9). Also, the strong growth of livestock herds in this region determined output expansion (Fig. 7). To what extent technological upgrading, such as new seed varieties, improved agronomic practices or irrigation facilities, or mechanization are responsible for output growth remains unclear and should be investigated further.

Another understudied area concerns the role of international donors in farm restructuring, especially in Central Asia and the Transcaucasus. Lerman and Sedik (2018, pp. 910-911) credit the international community for instigating deep restructuring and individualization in Central Asia by lobbying central policymakers, thus compensating the lacking political representation of smallholders. Hofman (2018) voices a much more cautious note by stressing the various alternative strategies that allow political elites to continue their influence on production decisions and subvert individualization, even in the face of international donor pressure. 


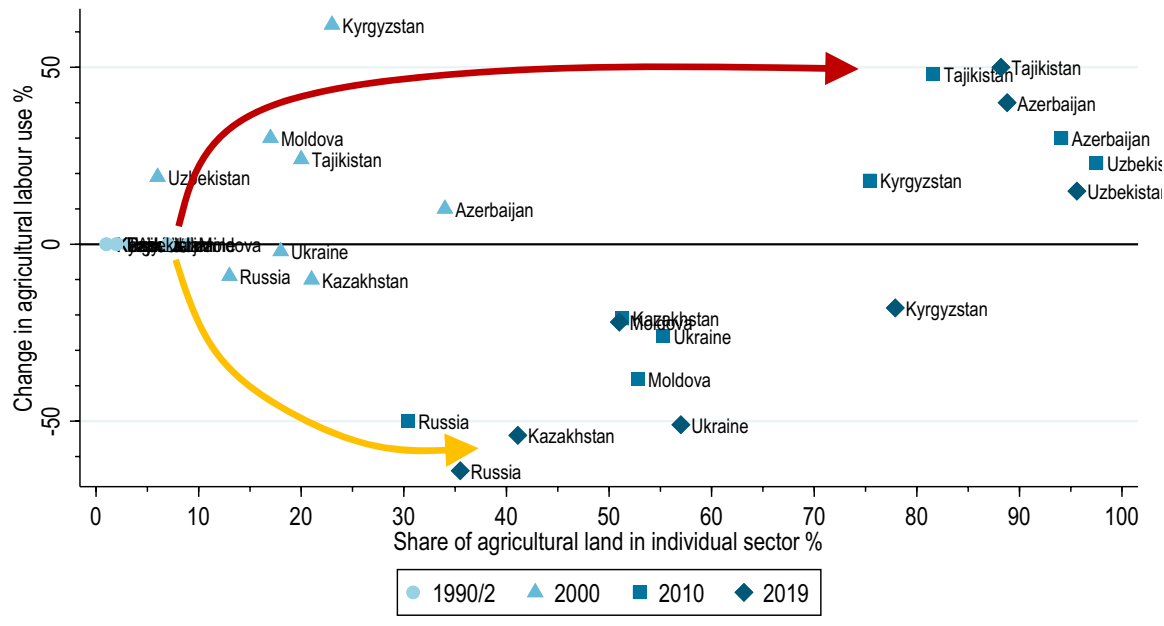

Fig. 5 Farm individualization and change in labor use (\%), 1990-2019. Note: Change in labor use is relative to 1992. Source: As in Fig. 3 and Fig. 8

\section{Evaluating the Overall Reform Dynamics}

Returning to the claim that farm individualization is the key driver of productivity increases, I now relate the output and productivity indicators presented before to the progress in farm individualization. Taken at face value, Fig. 4 clearly supports the idea that full individualization coincides with the highest output growth, compared with the unreformed ex ante situation. Moreover, it suggests that half-hearted individualization makes matters even worse, indicated by the output contraction observed in the middle of the horizontal axis. But do these numbers corroborate the hypothesis that individualization is the ultimate cause of output growth? Without controlling for other factors of production, it seems premature to draw such a conclusion from a simple bivariate relationship.

Indeed, considering how labor use in agriculture changed along with individualization leads to a very different assessment. As noted before, labor input changed dramatically over the 30 years of period (Fig. 8). Plotted against the progress in individualization, two clearly distinguishable country clusters emerge (Fig. 5). In the Transcaucasus and Central Asia, farm operations highly individualized, but also experienced a strong growth in the labor force. In the European CIS and Kazakhstan, corporate farms stayed put as key players, but experienced a drastic decline in workers (see also Nefedova 2017). Along with individualization, labor input thus massively increased in the countries with the highest output growth.

It is thus difficult to decide whether individualization or rising labor input triggered output growth in the Transcaucasus and Central Asia. Similarly, other potential determinants of output growth should be taken into account, such as capital input or output price changes. Restructuring of corporate farms has often involved the substitution of capital for labor, whereas many individual farms in the Transcaucasus or Central Asia lack access to capital (see e.g., Petrick et al. 2017). 


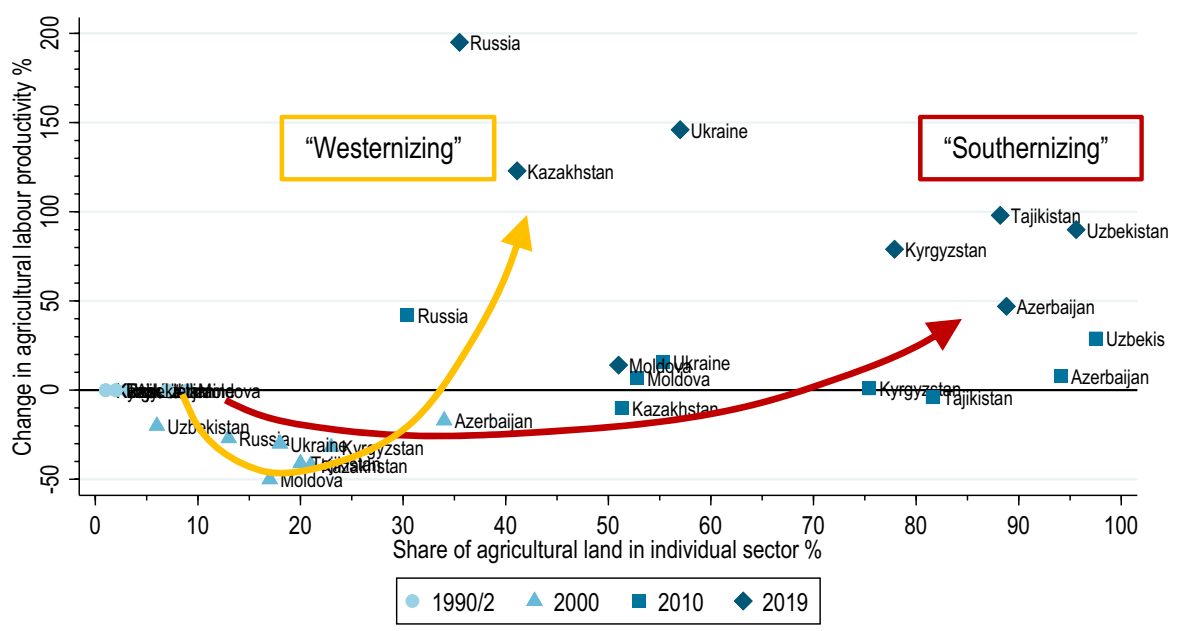

Fig. 6 Farm individualization and change in labor productivity (\%), 1990-2019. Note: productivity change is relative to 1992. Source: As in Figs. 2 and 3

Due to a lack of data, I cannot pursue a more comprehensive analysis of productivity growth here. ${ }^{8}$ But assembling the existing quantitative evidence presented so far allows some tentative conclusions on the overall role of farm individualization nevertheless. Looking back on the post-Soviet region after 30 years, agricultural restructuring followed two major pathways (Fig. 6):

- In the European CIS and Kazakhstan, at most half of the agricultural land formerly held by collectives moved into individual farms. At the same time, many rural areas experienced an exodus of workers, while external investors recapitalized and modernized the existing corporate farms. I label this path the "Westernization" of post-Soviet agriculture. It marks the familiar processes of factor substitution in the course of economic development. But also the coexistence of corporate and family farming models and their vertical integration into value chains increasingly characterize agricultural sector evolution in this group of countries, as well as in many Western economies (see e.g., Sumner 2014).

- In contrast, the Transcaucasus and Central Asia experienced an almost complete shift to individualized farming. But a lack of outside economic opportunities and high fertility rates keep workers in agriculture, unless they migrate abroad. Because capital penetrates agriculture only slowly, it is primarily the increasing labor intensity that contributes to output growth in tandem with improved incentives from farm individualization. After 30 years, the growth in agricultural labor productivity remains much more limited than in the countries following the first pathway. While output in dollars per worker was already lower compared to

\footnotetext{
${ }^{8}$ Unfortunately, the methodologically sophisticated analysis of agricultural productivity in Russian regions by Rada et al. (2020) did not consider farm individualization as a growth determinant.
} 
the first group at the outset of transition, the difference in absolute terms is now even larger (Fig. 11). As it resembles the conditions in agriculture of much of the Global South (Gollin et al. 2014), I label this path the "Southernization" of postSoviet agriculture.

In addition to relative overemployment and low labor productivity, rural areas in the Transcaucasus and Central Asia group also display other features known from agriculture in low-income countries. Rural poverty remains a challenge in several countries of the region (Akramov et al. 2020). Contractual relations are characterized by informality, patronage and power asymmetries, as documented by a now sizeable literature on irrigation governance and land tenure in Central Asia (e.g., Djanibekov et al. 2013; Mukhamedova and Pomfret 2019).

Defying the contrast between the two groups of countries, the continuity of rural household production represents a notable commonality among them. In all countries covered here, a mostly static, subsistence-oriented household sector has resisted political upheaval and economic hardship (Fig. 9). In rural economies following the pattern of "Westernization," it thus perpetuated a strongly bi-modal or polarized farm structure that already existed during Soviet times (Sedik et al. 2018). In "Southernizing" countries, the border with individual farms is often vague and may be difficult to define empirically. I consider the persistence of the rural household producers as one of the unifying structural elements across the region that still justifies the label "post-Soviet" for its entirety.

\section{Conclusions}

Have 30 years of post-Soviet agricultural restructuring turned into a success story? In an imaginary current day visit to the region, the initial proponents of the "family farm theory" would probably be surprised to see that corporate farms still (or again!) play a central role in the "breadbasket" of the Eurasian steppe. Hopes that individual farming would win the day across the region did not materialize. ${ }^{9}$ The clear "transition" goal of the 1990s has given way to a more diverse set of trajectories, with their destinations often blurred.

In the European CIS countries and Kazakhstan, representing 93\% of the arable land of the former Soviet Union, other factors than the superiority of labor incentives among family workers or the absence of scale economies in primary production proved to be more relevant for the restructuring outcomes to date. Access to

\footnotetext{
9 Some experts knew it all along. In a still authoritative monograph on the subject, the late Frederic L. Pryor (1992, p. 295) wrote: "In considering the rise and fall of collectivized agriculture, I am sorely tempted to add a question mark after the word fall. This system of capital-intensive, estate farming with a large labor force may remain in many countries, albeit not so extensive as in the 1980s. Indeed, it may prove to be one of Stalin's lasting legacies."
} 
corporate management, capital and political support as well as vertical integration played crucial roles in a change trajectory I labelled the "Westernization" of agriculture.

While restructuring in the Transcaucasus and Central Asia almost accomplished the goal of full individualization, operators in this part of the region struggle to wrestle a decent living from their reformed farming units. After 30 years, agricultural labor productivity lags much behind the group of European CIS countries and Kazakhstan, and even more behind the early reformers in Central Europe and the Baltics. Here, de-collectivization often contributed to a more egalitarian access of the rural population to productive resources. However, what I call the "Southernization" of post-Soviet agriculture also echoes concerns about overpopulation, informality and poverty that are prominent in development discourses in the Global South.

Potentially disappointing the Western reform proponents of the first days of transition, these empirical patterns correspond well with an emerging literature arguing that the low labor productivity on small farms is a sign of resource misallocation (Adamopoulos and Restuccia 2014). These authors assert that labor productivity gaps disappear with economy-wide income growth, urbanization and larger farm sizes (Gollin 2018). The findings here on the correlation of corporatization, rural outmigration and labor productivity in the European CIS confirm exactly this.

Moreover, recent scholarship stresses the importance of entrepreneurial talent and how it selects into certain farm sizes (Adamopoulos and Restuccia 2014; Gollin et al. 2014; Sumner 2014). Talented individuals may find it unattractive to manage small farms, as these fail to fulfil their income expectations, and they therefore choose other career paths or sectors. The traditional literature guiding the early transition debate mostly overlooked this success factor. Still today, little evidence on the role of skill in post-Soviet farm restructuring exists.

In this view, rather than giving first priority to strong property rights in land, policymakers should focus their attention on fluid factor markets, including for land, that allow a better match of physical resources with talent. In overpopulated rural areas, smallholder farming is at best a temporary solution to buffer economic hardship and the absence of better opportunities outside agriculture. A key task for governments is to encourage and safeguard the creation of such economic opportunity for all-perhaps inside, but especially outside the agricultural sector.

This article thus points out a couple of misconceptions found in the literature on post-Soviet agricultural restructuring. The analysis here refutes the notion that all post-socialist countries converge toward a fully individualized farming sector. Hence, farm individualization is not a success factor per se, and it is not the same as establishing strong property rights in land. Individual, smallholder and family farming are not the same. Individual farms in the "Westernizing" countries resemble commercial family farms in America or the European Union and often hire a significant number of workers. In the "Southernizing" countries, they typically control much less land per farm and often dedicate a relevant fraction of their resources to supply the operators with food. Both groups need to be 
distinguished from the omnipresent and rather static rural household plots already established during the Soviet Union.

Most countries in the CIS arguably still have a rather long way to go before land, labor and capital allocation concur with the ideal of a fluid market mechanism-a goal quite prominent in the early reform debates about "transition" to a market economy. Other than envisaged by authors like Gollin (2018), land is typically not flowing to the more talented entrepreneur via flexible and transparent rental or sales arrangements. Farm consolidation among more able managers often occurs through political patronage or networks within a small elite of investors, such as in the case of agro-holdings, or it does not occur at all, as land markets are paralyzed by legal provisions or political constraints (Visser et al. 2012; Lapa et al. 2015; Kvartiuk and Petrick 2021). Whether future reformers will manage to tackle these obstacles will be decided mostly outside the agricultural sector.

I conclude with pinpointing a number of areas where further empirical research could help to better understand and potentially shape the ongoing restructuring of post-Soviet agriculture:

- The farm-level drivers of rising productivity in different types of farms are surprisingly little understood. What explains the recent growth in labor productivity on Russian enterprises (a bit bafflingly called "informal technical change" by Rada et al. 2020), and what the impressive rise in output per hectare in Central Asia and the Transcaucasus?

- Little is known about the internal management arrangements, the financial performance and the profitability of corporate farming structures across the region. Given widespread government protection, overt or not, the international competitiveness of large-scale farming is difficult to assess. Comprehensive analysis may require methods different from traditional farm surveys or accounting and may involve qualitative and/or participant social science opening the "black box" of such organizations.

- The "individual sector" consists of a heterogeneous mix of producers, some with commercial and some with subsistence orientation. Further micro-analysis is required into the characteristics of these different groups and their development trajectories over time.

- The future access of skilled managers to the agricultural sector will play a decisive role for further growth and employment, and also its strategic readjustment, e.g., with regard to livestock or high value crops. Just how did or could managers with a possibly non-agricultural background make their fortune in the sector (Kvartiuk et al. 2020)? How might negative stereotypes about agricultural backwardness be overcome?

- Given the stunning growth of livestock in the Transcaucasus and Central Asia and its return to the agricultural policy agenda in the European CIS, what are the drivers and perspectives of this re-emergence? Which impact does it have on rural livelihoods and the natural environment?

- Compared to other world regions, the role of international donors in agricultural restructuring has gained little attention from independent scholarship, neither 
in the early restructuring debates of the European CIS, nor in places like Kyrgyzstan or Tajikistan more recently. Which were the impacts of donor activity and how well was it aligned with or possibly counteracted by local stakeholders?

\section{Appendix}

\section{See Tables 2 and 3.}

Table 2 Land use among agricultural enterprises, individual farms and households (thousand hectares of agricultural land), 2010 and 2019

\begin{tabular}{lrrrr}
\hline & Year & Ag. enterprises & Individual farms & Rural households \\
\hline Russia & 2010 & 122111.0 & 23771.0 & 29683.0 \\
& 2019 & 114847.0 & 28637.0 & 34671.0 \\
Ukraine & 2010 & 16298.8 & 4290.8 & 15898.3 \\
& 2019 & 15364.1 & 4749.5 & 15640.0 \\
Moldova & 2010 & 871.3 & 661.4 & 313.6 \\
& 2019 & 908.5 & 609.7 & 335.9 \\
Azerbaijan $^{\mathrm{a}}$ & 2010 & 92.9 & 33.8 & 1457.2 \\
& 2019 & 192.6 & 7.0 & 1517.5 \\
Kazakhstan $^{\mathrm{a}}$ & 2010 & 13105.3 & 8075.4 & 258.0 \\
Kyrgyzstan $^{\mathrm{a}}$ & 2019 & 13043.1 & 8892.6 & 200.0 \\
& 2010 & 311.0 & 881.8 & 69.1 \\
Tajikistan $^{\mathrm{a}}$ & 2019 & 283.0 & 925.5 & 73.7 \\
& 2010 & 154.3 & 494.9 & 190.0 \\
Uzbekistan $^{\mathrm{a}}$ & 2019 & 119.5 & 556.3 & 171.2 \\
& 2010 & 93.9 & 3143.0 & 471.5 \\
\hline & 2019 & 213.3 & 2623.2 & 472.9
\end{tabular}

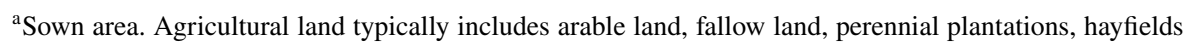
and pastures. In Russia, households possess relatively more hayfields, perennials and fallow than the other two types of farms, so that their share is smaller in sown area compared to agricultural land 
Table 3 Gross Agricultural Output in agricultural enterprises, individual farms and households (local currency), 2010 and 2019 or latest available. Sources of Tables 2 and 3: Russia, Ukraine, Kazakhstan, Kyrgyzstan, Tajikistan, Uzbekistan: Statistical Yearbooks of Agriculture published by National Statistical Offices, various issues; Moldova: Activities of Small Agricultural Producers in the Republic of Moldova published by National Statistical Office; Azerbaijan: Main economic indicators of agricultural enterprises and private farms, additional spreadsheets published at https://www.stat.gov.az/

\begin{tabular}{lrrrrl}
\hline & Year & $\begin{array}{c}\text { Agricultural } \\
\text { enterprises }\end{array}$ & Individual farms & Rural households & Units \\
\hline Russia & 2010 & 1150.0 & 187.4 & 1250.4 & Billion ruble \\
Russia & 2018 & 3022.1 & 670.0 & 1656.7 & Billion ruble \\
Ukraine & 2010 & 40136.3 & 5012.9 & 55387.0 & 2005 Million hryvnia \\
Ukraine & 2019 & 449806.3 & 79053.0 & 231176.1 & 2016 Million hryvnia \\
Moldova & 2010 & 9638.4 & 3875.2 & 6359.4 & Million lei \\
Moldova & 2018 & 11651.4 & 7017.0 & 13968.6 & Million lei \\
Azerbaijan & 2010 & 192.6 & 18.9 & 3666.2 & Million manat \\
Azerbaijan & 2019 & 713.2 & 24.4 & 7099.1 & Million manat \\
Kazakhstan & 2010 & 275945.1 & 345661.6 & 818291.5 & Million tenge \\
Kazakhstan & 2019 & 1293980.0 & 1607788.5 & 2276125.2 & Million tenge \\
Kyrgyzstan & 2010 & 2754.3 & 69235.5 & 40505.3 & Million som \\
Kyrgyzstan & 2018 & 3520.3 & 124932.7 & 71081.1 & Million som \\
Tajikistan & 2010 & 562505.0 & 2284969.0 & 1762427.0 & Thousand somoni \\
Tajikistan & 2019 & 2101.5 & 11379.0 & 14269.9 & 2016 Million somoni \\
Uzbekistan & 2010 & 343.0 & 5962.8 & 10468.9 & Billion som \\
Uzbekistan & 2019 & 8262.5 & 60394.7 & 147625.9 & Billion som \\
\hline & & & & & \\
\hline
\end{tabular}

See Figs. 7, 8, 9, 10, 11.

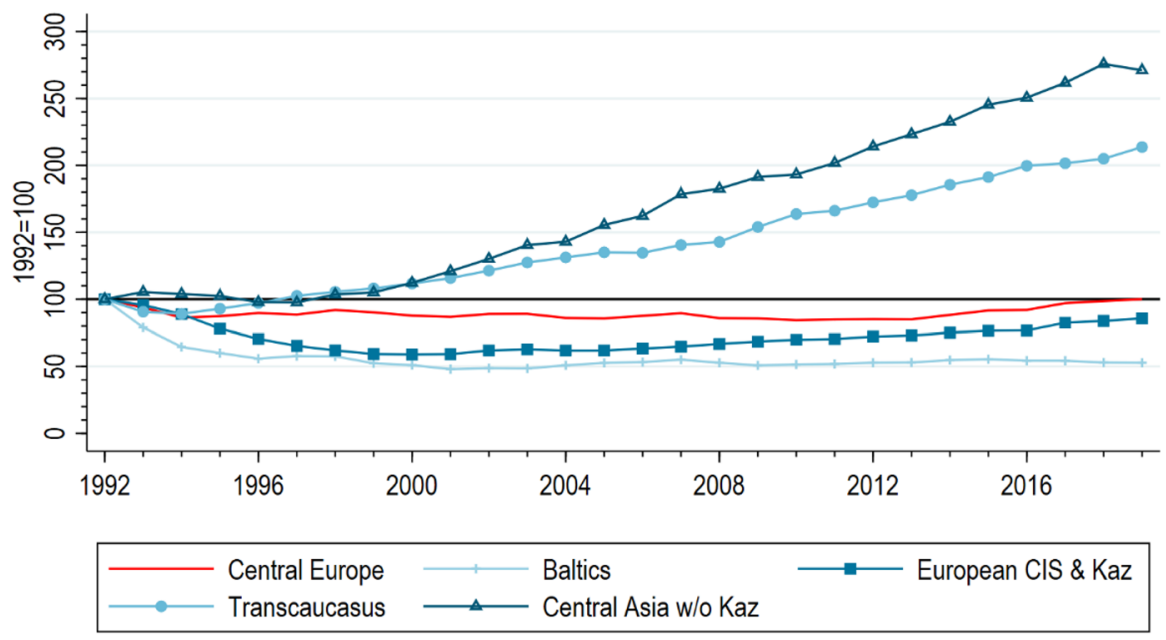

Fig. 7 Livestock production index in post-socialist country groups $(1992=100), 1992-2019$. Source: Author based on FAO data 


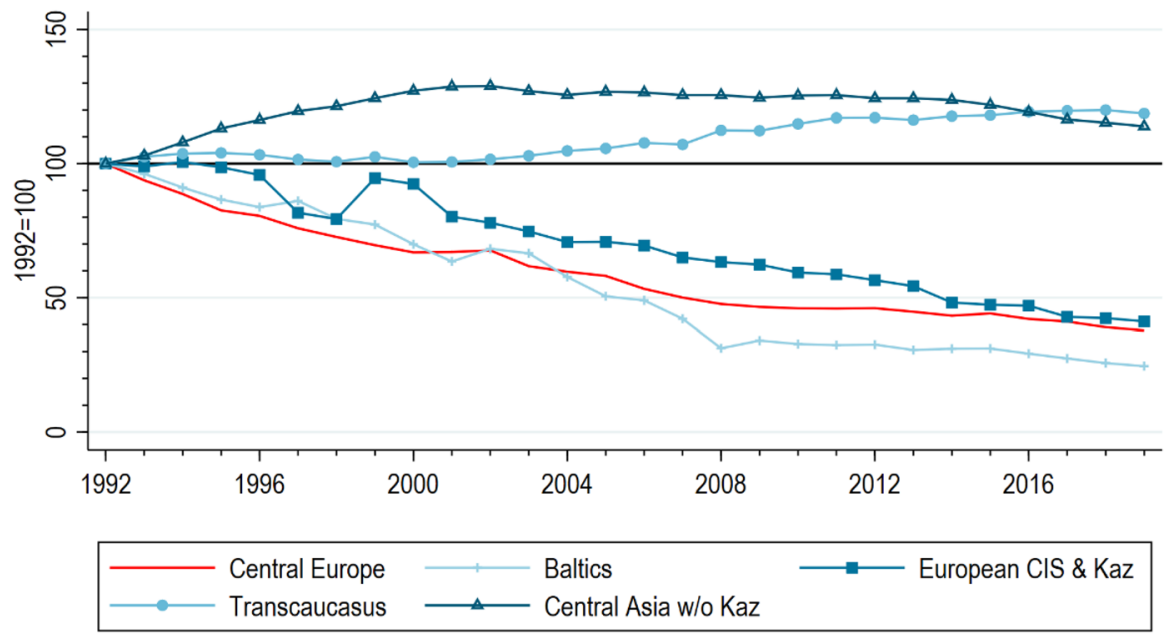

Fig. 8 Agricultural labor use index in post-socialist country groups (1992=100), 1992-2019. Source: Author based on ILO data

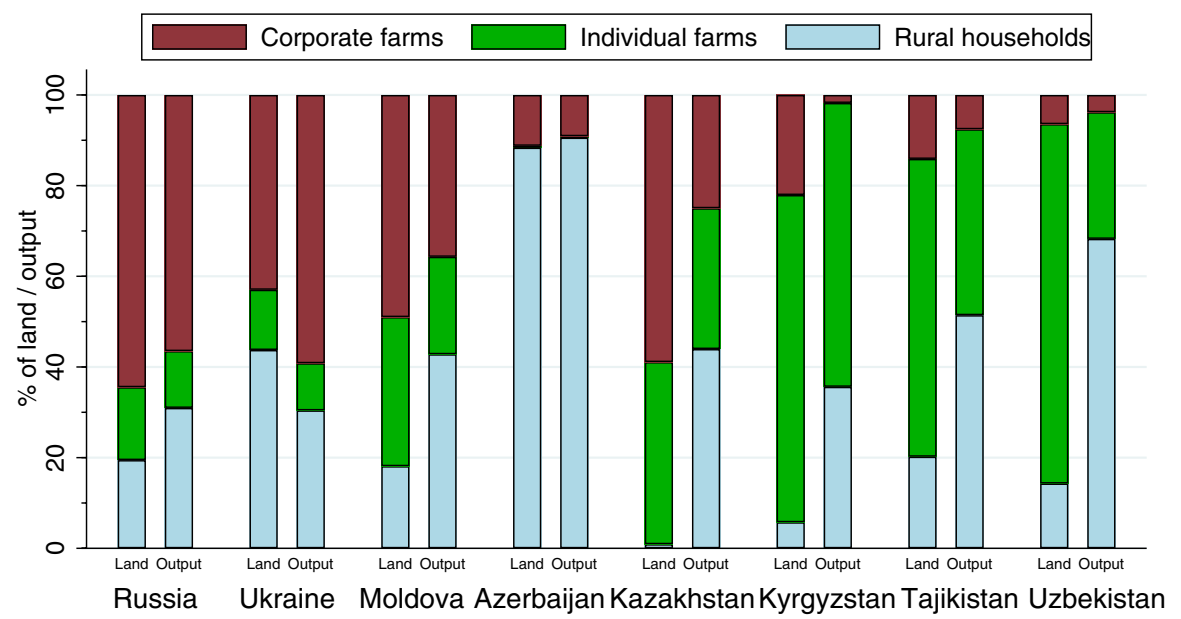

Fig. 9 Current land use and contribution to output by farm type. Note: Data for 2019, output data is 2018 for Russia, Moldova and Kyrgyzstan Source: National statistical offices 


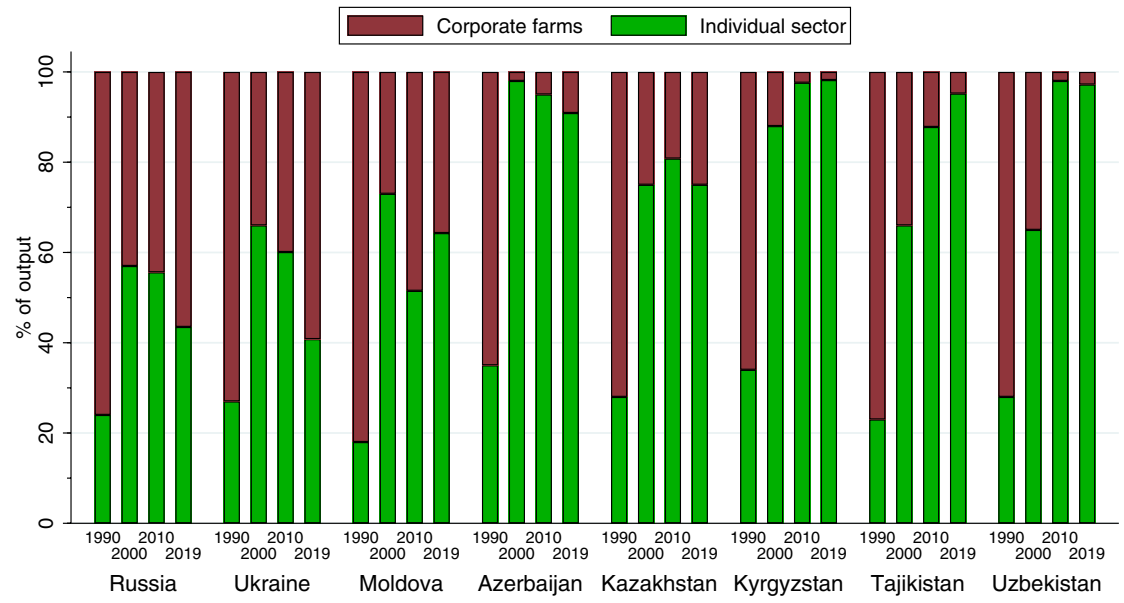

Fig. 10 GAO by farm type, 1990-2019. Note: individual sector includes individual farms and rural households. Source: National statistical offices, Lerman et al. (2004, p. 113) for 1990 and 2000

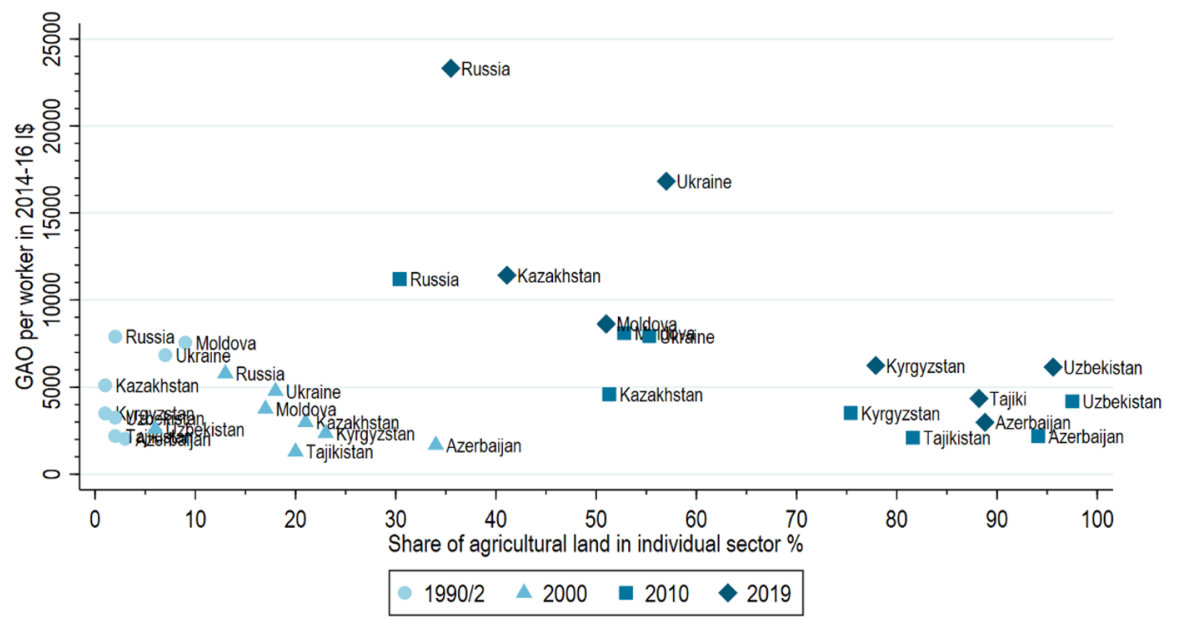

Fig. 11 Farm individualization and GAO per worker (2014-2016 international \$), 1990-2019. Note: GAO per worker relates to 1992 Source: Author based on FAO and data in Fig. 3

Acknowledgements I am grateful to participants of the session "Thirty Years since Dissolution of the Soviet Union" hosted by the Association for Comparative Economic Studies at the 2021 meeting of the Allied Social Science Associations, and to Nodir Djanibekov, Linde Götz, Irna Hofman, Stephan Merl, Aleksandr Nikulin, Sarah Robinson, and an anonymous referee for useful discussions and constructive feedback on earlier versions of the manuscript. The usual disclaimer applies.

Funding Open Access funding enabled and organized by Projekt DEAL. My work on this article was supported by the VolkswagenStiftung "SUSADICA-Structured doctoral programme on Sustainable Agricultural Development in Central Asia" (Grant Number 96 264) and the German Academic Exchange Service (DAAD) from funds of the Federal Ministry for Economic Cooperation (BMZ), 
SDGnexus Network (Grant Number 57526248), program "exceed-Hochschulexzellenz in der Entwicklungszusammenarbeit."

Open Access This article is licensed under a Creative Commons Attribution 4.0 International License, which permits use, sharing, adaptation, distribution and reproduction in any medium or format, as long as you give appropriate credit to the original author(s) and the source, provide a link to the Creative Commons licence, and indicate if changes were made. The images or other third party material in this article are included in the article's Creative Commons licence, unless indicated otherwise in a credit line to the material. If material is not included in the article's Creative Commons licence and your intended use is not permitted by statutory regulation or exceeds the permitted use, you will need to obtain permission directly from the copyright holder. To view a copy of this licence, visit http://creativecommons.org/licen ses/by/4.0/.

\section{References}

Adamopoulos, T., and D. Restuccia. 2014. The size distribution of farms and international productivity differences. American Economic Review 104(6): 1667-1697.

Akramov, K.T., R. Romashkin, A. Park, and J. Ilyasov. 2020. Central Asia. IFPRI global food policy report 2020 regional developments. Washington, DC: IFPRI.

Allina-Pisano, J. 2008. The post-Soviet Potemkin village: Politics and property rights in the black earth. Cambridge: Cambridge University Press.

Binswanger, H.P., K. Deininger, and G. Feder. 1995. Power, distortions, revolt and reform in agricultural land relations. In Handbook of development economics, ed. J. Behrman and T.N. Srinivasan, vol. III, 2659-2772. Amsterdam: Elsevier.

Boserup, E. 1965. The conditions of agricultural growth: The economics of agrarian change under population pressure. Chicago: George Allen \& Unwin.

Burkitbayeva, S., and J. Swinnen. 2018. Smallholder agriculture in transition economies. Journal of Agrarian Change 18(4): 882-892.

Djanibekov, N., K. van Assche, I. Bobojonov, and J.P.A. Lamers. 2012. Farm restructuring and land consolidation in Uzbekistan: New farms with old barriers. Europe-Asia Studies 64: 1101-1126.

Djanibekov, U., K. van Assche, D. Boezeman, and N. Djanibekov. 2013. Understanding contracts in evolving agro-economies: Fermers, dekhqans and networks in Khorezm, Uzbekistan. Journal of Rural Studies 32: 137-147.

FAO. 2021. FAOSTAT database, http://www.fao.org/faostat/en/\#home. Accessed 24 Apr 2021.

Gollin, D., D. Lagakos, and M.E. Waugh. 2014. The agricultural productivity gap. Quarterly Journal of Economics 129(2): 939-993.

Gollin, D. 2018. Farm size and productivity. Lessons from recent literature, IFAD Research Series 34. Rome: IFAD.

Graubner, M., I. Ostapchuk, and T. Gagalyuk. 2021. Agroholdings and land rental markets: A spatial competition perspective. European Review of Agricultural Economics 48: 158-206.

Hofman, I. 2018. Soft budgets and elastic debt: farm liabilities in the agrarian political economy of post-Soviet Tajikistan. Journal of Peasant Studies 45(7): 1360-1381.

Johnson, D.G. 1993. Historical Experience of Eastern and Central European and Soviet Agriculture. In The agricultural transition in Central and Eastern Europe and the former U.S.S.R. A World Bank Symposium, ed. A. Braverman, K.M. Brooks, and C. Csaki, 11-26. Washington, DC: World Bank.

Kislev, Y., and W. Peterson. 1982. Prices, technology, and farm size. Journal of Political Economy 90: 578-595.

Kvartiuk, V., and M. Petrick. 2021. Liberal land reform in Kazakhstan? The effect on land rental and credit markets. World Development 138: 105285.

Kvartiuk, V., M. Petrick, M. Bavorova, Z. Bednaříková, and E. Ponkina. 2020. A brain drain in Russian Agriculture? Migration sentiments among skilled Russian rural youth. Europe-Asia Studies 72(8): $1352-1377$. 
Lapa, V., T. Gagalyuk, and I. Ostapchuk. 2015. The emergence of agroholdings and patterns of land use in Ukraine. In Transition to agricultural market economies: The future of Kazakhstan, Russia, and Ukraine, ed. A. Schmitz and W.H. Meyers, 102-110. Wallingford (UK): CABI.

Lerman, Z. 1998. Does land reform matter? Some experiences from the former Soviet Union. European Review of Agricultural Economics 25: 307-330.

Lerman, Z. 2017. Privatisation and changing farm structures in the Commonwealth of Independent States. In The Eurasian wheat belt and food security: Global and regional aspects, ed. S. Gomez y Paloma, S. Mary, S. Langrell, and P. Ciaian, 15-32. New York: Springer.

Lerman, Z., and D. Sedik. 2018. Transition to smallholder agriculture in Central Asia. Journal of Agrarian Change 18(4): 904-912.

Lerman, Z., C. Csaki, and G. Feder. 2004. Agriculture in transition: Land policies and evolving farm structures in post-Soviet countries. Lanham: Lexington Books.

Lerman, Z., D. Sedik, N. Pugachov, and A. Goncharuk. 2007. Rethinking agricultural reform in Ukraine. Halle (Saale): IAMO.

Lipton, M., and Y. Saghai. 2017. Food security, farmland access ethics, and land reform. Global Food Security 12: 59-66.

Mukhamedova, N., and R. Pomfret. 2019. Why does sharecropping survive? Agrarian institutions and contract choice in Kazakhstan and Uzbekistan. Comparative Economic Studies 61(4): 576-597.

Nefedova, T.G. 2017. Twenty-five years of Russia's post-Soviet agriculture: Geographical trends and contradictions. Regional Research of Russia 7(4): 311-321.

Pallot, J., and T.G. Nefedova. 2007. Russia's unknown agriculture: Household production in post-socialist Russia. Oxford: Oxford University Press.

Petrick, M., and M.R. Carter. 2009. Critical masses in the decollectivisation of post-Soviet agriculture. European Review of Agricultural Economics 36: 231-252.

Petrick, M., and L. Götz. 2019. Herd growth, farm organisation and subsidies in the dairy sector of Russia and Kazakhstan. Journal of Agricultural Economics 70(3): 789-811.

Petrick, M., J. Wandel, and K. Karsten. 2013. Rediscovering the virgin lands: Agricultural investment and rural livelihoods in a Eurasian frontier area. World Development 43: 164-179.

Petrick, M., D. Oshakbaev, and J. Wandel. 2017. More than pouring money into an ailing sector? Farmlevel financial constraints and Kazakhstan's 'Agribusiness 2020' strategy. In The Eurasian wheat belt and food security: Global and regional aspects, ed. S. Gomez y Paloma, S. Mary, S. Langrell, and P. Ciaian, 103-118. New York: Springer.

Pryor, F.L. 1992. The red and the green: The rise and fall of collectivized agriculture in Marxist regimes. Princeton: Princeton University Press.

Rada, N., W. Liefert, and O. Liefert. 2020. Evaluating agricultural productivity and policy in Russia. Journal of Agricultural Economics 71(1): 96-117.

Robinson, S., and M. Petrick. 2021. Trade-offs among sustainability goals in the Central Asian livestock sector: A research review, SDGnexus Network Working Paper 01-2021. Gießen: Center for international Development and Environmental Research (ZEU).

Rylko, D., I. Khramova, V. Uzun, and R. Jolly. 2008. Agroholdings: Russia's new agricultural operators. In Russia's agriculture in transition: Factor markets and constraints on growth, rural economies in transition, ed. Z. Lerman, 95-133. Lanham: Lexington Books.

Sarris, A.H., T. Doucha, and E. Mathijs. 1999. Agricultural restructuring in central and eastern Europe: Implications for competitiveness and rural development. European Review of Agricultural Economics 26: 305-329.

Schierhorn, F., D. Müller, T. Beringer, A.V. Prishchepov, T. Kuemmerle, and A. Balmann. 2013. PostSoviet cropland abandonment and carbon sequestration in European Russia, Ukraine, and Belarus. Global Biochemical Cycles 27(4): 1175-1185.

Schmitt, G. 1991. Why is the agriculture of advanced Western economies still organized by family farms? Will this continue to be so in the future? European Review of Agricultural Economics 18: 443-458.

Sedik, D., Z. Lerman, N. Shagaida, V. Uzun, and R. Yanbykh. 2018. Agricultural and rural policies in Russia. In Handbook on international food and agricultural policy: Volume I: Policies for agricultural markets and rural economic activity, ed. W.H. Meyers and T. Johnson, 433-460. Singapore: World Scientific.

Shagaida, N., and Z. Lerman. 2017. Land policy in Russia: New challenges. In The Eurasian wheat belt and food security: Global and regional aspects, ed. S. Gomez y Paloma, S. Mary, S. Langrell, and P. Ciaian, 33-50. New York: Springer. 
Stiglitz, J.E. 1993. Incentives, organizational structures, and contractual choice in the reform of socialist agriculture. In The agricultural transition in Central and Eastern Europe and the former U.S.S.R. A World Bank Symposium, ed. A. Braverman, K.M. Brooks, and C. Csaki, 27-46. Washington, DC: World Bank.

Sumner, D.A. 2014. American farms keep growing: size, productivity, and policy. Journal of Economic Perspectives 28: 147-166.

Swinnen, J.F.M., and S. Rozelle. 2006. From Marx and Mao to the Market: The economics and politics of agricultural transition. Oxford: Oxford University Press.

Uzun, V., N. Shagaida, and Z. Lerman. 2019. Russian agriculture: Growth and institutional challenges. Land Use Policy 83: 475-487.

Van Atta, D. (ed.). 1993. The "Farmer threat": The political economy of agrarian reform in post-Soviet Russia. Boulder: Westview Press.

Veldwisch, G.J., and M. Spoor. 2008. Contesting rural resources: Emerging "Forms" of Agrarian production in Uzbekistan. Journal of Peasant Studies 35(3): 424-451.

Visser, O., N. Mamonova, and M. Spoor. 2012. Oligarchs, megafarms and land reserves: Understanding land grabbing in Russia. Journal of Peasant Studies 39: 899-931.

Wädekin, K.-E. 1973. The private sector in Soviet agriculture. Berkeley: University of California Press.

Wegren, S.K. 2005. The moral economy reconsidered: Russia's search for agrarian capitalism. Basingstoke: Palgrave Macmillan.

Wegren, S.K. 2011. Private farming in Russia: An emerging success? Post-Soviet Affairs 27(3): 211-240.

World Bank. 1992. Food and Agricultural Policy Reforms in the Former USSR. An Agenda for the Transition, Studies of Economies in Transformation 1. Washington, DC: World Bank.

World Bank. 2020. World Development Indicators database, https://databank.worldbank.org/source/ world-development-indicators. Accessed 04 Oct 2020.

Yanbykh, R., V. Saraikin, and Z. Lerman. 2020. Changes in Russia's agrarian structure: What can we learn from agricultural census? Russian Journal of Economics 6(1): 26-41.

Zorya, S., N. Djanibekov, and M. Petrick. 2019. Farm restructuring in Uzbekistan: How did it go and what is next? ASA "support to Agricultural Modernization in Uzbekistan". Washington, DC: World Bank.

Publisher's Note Springer Nature remains neutral with regard to jurisdictional claims in published maps and institutional affiliations. 